\title{
The Effect of Teaching Strategy Based on Multiple Intelligences on Students' Academic Achievement in Science Course
}

\author{
Ali abdi ${ }^{1, *}$, Soosan Laei $^{2}$, Hamze Ahmadyan ${ }^{3}$ \\ ${ }^{1}$ Department of Educational Sciences Payame noor University, Iran \\ ${ }^{2}$ Department of Educational Sciences, Kermanshah Branch, Islamic Azad University, Kermanshah, Iran \\ ${ }^{3}$ Department of psychology Azad University of sanandaj branch, Iran \\ Corresponding Author: raziali88@gmail.com
}

Copyright $(2013$ Horizon Research Publishing All rights reserved.

\begin{abstract}
The purpose of this study was to investigate the effects of Teaching Strategy based on Multiple Intelligences on students' academic achievement in sciences course. Totally 40 students from two different classes (Experimental $\mathrm{N}=20$ and Control $\mathrm{N}=20$ ) participated in the study. They were in the fifth grade of elementary school and were selected through multi-stage clustered sampling. The group which was assigned as experimental group was instructed through Teaching Strategy based on Multiple Intelligences whereas the other group was traditionally instructed. This experimental study lasted 8 weeks. To determine the effectiveness of Teaching Strategy based on Multiple Intelligences over common teaching method (traditional instruction), an achievement test about sciences which consisted of 30 items was administered. For the statistical analysis, Analysis of Covariance (ANCOVA) was used. The results showed that students who were instructed through Teaching Strategy based on Multiple Intelligences were achieved higher score than the ones which were instructed through the traditional instruction.
\end{abstract}

Keywords Sciences Lesson, Teaching Strategy Based on Multiple Intelligences, Students Academic Achievement

\section{Introduction}

Good elementary science education can do much to provide a sound foundation for later learning, as well as helping students become comfortable with using science and scientific thinking in their daily lives, whether in a career or as consumers and citizens (Aschbacher \& Pine, 2006, p. 308). Rubba and Andersen (1978), Hurd (1970) and Klopfer (1971) indicate that the major goal of science education should be developing students "scientific literacy". Since the goal of science education is related to very important questions which are "why teach science to who teach science and at what level", there is a relationship between the method of instruction and the attainment of objectives (Baez, 1971). Among these different kinds of methodologies, Multiple Intelligence-based instruction has an important place. The multiple intelligences theory (Gardner, 1999, 2004) has significant implications for education in general, and can help students' achievements ameliorate, in particular (Barrington 2004; Christion \& Kennedy, 2004; Ozdemir, Guneysu, \& Tekkaya, 2006). Intelligence has traditionally been defined in terms of intelligence quotient (IQ), which measures a narrow range of verbal/linguistic and logical/mathematical abilities (Christison, 1996). Gardner (1993) argues that humans possess a number of distinct intelligences that manifest themselves in different skills and abilities. All human beings apply these intelligences to solve problems, invent processes, and create things. Intelligence, according to multiple intelligences theory, is being able to apply one or more of the intelligences in ways that are valued by a community or culture. The current Multiple Intelligences Theory outlines eight intelligences, although Gardner (1993, 1999) continues to explore additional possibilities:

1) Verbal / Linguistic Intelligence: The ability to use language effectively both orally and in writing. 2) Logical/Mathematical Intelligence: The ability to use numbers effectively and reason well. 3) Visual/Spatial Intelligence: The ability to recognise form, space, colour, line, and shape and to graphically represent visual and spatial ideas. 4) Bodily/Kinaesthetic Intelligence: The ability to use the body to express ideas and feelings and to solve problems. 5) Musical Intelligence: The ability to recognise rhythm, pitch, and melody. 6) Interpersonal Intelligence: The ability to understand another person's feelings, motivations, and intentions and to respond effectively. 7) Intrapersonal Intelligence: The ability to know about and understand oneself and recognise one's similarities to and differences from others. 8) Naturalist Intelligence: The ability to recognise and classify plants, minerals, and animals. The 
theory of multiple intelligences offers eight ways of teaching and learning styles. In this regard, armed with the knowledge and application of the multiple intelligences, teachers can ensure they provide enough variety in the activities they use so that as much of their pupils' learning potential can be tapped as possible (Bas, 2008). Shore (2004) suggests, MI has united educators who need to provide educational experiences that are relevant to diverse learners. Multiple Intelligences helps educators support every learner by celebrating the kids who draw well, run fast, sing loud, socialize a lot, have a keen sense of self awareness, as well as those kids who just like collecting bugs (Whitaker, 2002). In the context of education and student achievement, Multiple Intelligence is especially powerful because it helps parents and teachers understand education holistically. Gardner (1994) says Multiple Intelligences persuades parents and teachers to examine their own ideas and assumptions about achievement and consider various teaching approaches. This suggestion provides a powerful lens to analyze multiple intelligences in the context of elementary student performance. Several studies (Campbell \& Campbell, 1999; Kornhaber, Fierros, \& Veenema, 2004), suggest multiple intelligence-based instruction increases student achievement. Ozdemir, Guneysu, and Tekkaya (2006), summarize a quantitative research project developed to investigate the difference between traditional, that is, direct-instruction facilitated by a teacher, and $\mathrm{m}$ science instruction on fourth grade students' understanding in science. The authors suggest that multiple intelligences serves as a "framework" that helps teachers "make decisions about ways to structure teaching and learning experiences for students" (p. 74). Specifically, multiple intelligence-based science instruction challenges students to develop meaningful understandings of the world around them and create connections between their lives and interests. Furthermore, multiple intelligences helps educators foster and cater to students' individual learning needs and preferences and links the classroom with the broader community. Most importantly, multiple intelligence-based instruction is a holistic and inclusive instructional model that helps educators create cross-curricular links and integrate different learning styles and abilities. So, the purpose of this study is to examine the effects of teaching Strategy based on Multiple Intelligences on Students' academic Achievement in Science Course as a school subject. This study, seeks the answer to the following question: Is teaching science with Strategy based on Multiple Intelligences on Students' academic Achievement in Science Course more effective than traditional science teaching methods?

\section{Method}

This research was a quasi-experimental study with non-equivalent groups, which includes pre and post-test design with the control group. Two classrooms of 5 th graders from yazdan bakhtiari Elementary School, Kermanshah, Iran formed the subjects of the study. The study was conducted with 20 experimental and 20 control group students. Both classes were taught by the same science teacher and both received identical syllabus-prescribed learning content. Academic Achievement Test was given to both groups as pre-test and post-test. The test included 30 multiple-choice items to measure the students' academic achievement. Each question had one correct answer and three 'distracters'. This was a teacher made test and it has been based on the table of specification. This table was organized for 3 chapters of the course "sciences education". The content validity of the study was examined by two sciences teachers, one researcher and one university professor. The internal consistency reliability (Cronbach's alpha) of this test was found to be 0.81 . The teacher was trained about the implementation of the multiple intelligences based instruction and the profiles of intelligences before the treatment. Student in the experimental group were instructed with multiple intelligences theory. Lesson plans about sciences education were planned in the light of this strategy. In 8 weeks, the experiment group was given various strategies for multiple intelligences in the teaching session Students carried out all the activities prepared in the light of eight multiple intelligence types in their learning environment. In the control group, a teacher directed strategy representing the traditional approach was used. The teacher lectured while standing in the front of the classroom, wrote on the blackboard, asked students questions about the assigned reading or handouts, waited while students finished their written work and gave daily homework to the students. Most of the time, the teacher presented the topic and the students listened and answered the questions that the teacher asked. The students carried out some activities given in their science textbook. The academic achievement was administrated to both groups in a single session as a pre-test. 8 weeks later, each of the groups was administrated the academic achievement tests given as a post-test. A one-way ANCOVA was conducted to analyze the data by the SPSS version 16.

\section{Research Findings}

Hypothesis: There will be no significant difference in the means score of students taught sciences education using multiple intelligence teaching strategy and those taught using conventional approach.

Table 1 presents means, standard deviations and Std. Error Means of each group on the pre-test and post-test scores.

Table 1 indicates that experimental group performed better than the control group as shown by the values of means and standard deviations but one cannot say whether these differences observed is significant or not.

In order to investigate a research hypothesis, on ANCOVA analysis was applied. 
Table 1. Means, Standard Deviations and Std. Error Mean of the Experimental and Control Groups for Pretests and posttest scores in academic achievement test

\begin{tabular}{cccccc}
\hline \multirow{2}{*}{ variable } & group & $\mathrm{N}$ & Mean & $\begin{array}{c}\text { Std. } \\
\text { Deviatio } \\
\mathrm{n}\end{array}$ & $\begin{array}{c}\text { Std. Error } \\
\text { Mean }\end{array}$ \\
\hline \multirow{2}{*}{ Pre-test } & experimental & 20 & 8.15 & 2.739 & .612 \\
& control & 20 & 8.75 & 3.177 & .710 \\
\multirow{2}{*}{ Post-test } & experimental & 20 & 24.60 & 4.147 & .927 \\
& control & 20 & 17.55 & 4.110 & .919 \\
\hline
\end{tabular}

In the table 2 data on ANCOVA analysis for the differences in post-test scores between experimental and control groups in academic achievement test has been shown.

Table 2. ANCOVA analysis for the differences in post-test mean scores between experimental and control groups in academic achievement test

\begin{tabular}{cccccc}
\hline Source & $\begin{array}{c}\text { Sum of } \\
\text { Squares }\end{array}$ & df & $\begin{array}{c}\text { Mean } \\
\text { Square }\end{array}$ & F & Sig. \\
\hline pre & 8.056 & 1 & 8.056 & .540 & .467 \\
Group & 104.025 & 1 & 104.025 & 6.969 & .012 \\
Error & 537.371 & 36 & 14.927 & & \\
Total & 18911.000 & 40 & & & \\
\hline
\end{tabular}

Table 2 indicates that the $(\mathrm{F})$ value was (6.969) and it was significant value at the level (.012). This means that there is a significant difference in the means score of students taught sciences education using multiple intelligence teaching strategy and those taught using conventional approach.

\section{Conclusion}

Based on the findings obtained in the study, it can be said that there is a significant difference between the achievement levels of the students who have been educated by teaching Strategy based on Multiple Intelligences and the students who have been educated by the traditional teaching methods. The students who have been educated by Strategy based on Multiple Intelligences have become more successful than the students who have been educated by the traditional teaching methods. The result of the present study are in line with other researchers such as Harriman (2010), Bellflower ( 2008), Douglas , Burton , Durham.(2008), Cooper (2008), Johnson (2007), Mussen(2007), Koksal \& Yel(2007), Ozdemir, Guneysu, \& Tekkaya, (2006), Ozdener \& Ozcoban (2004). When students are offered a variety of learning experiences they become actively engaged and invested in their individual learning process. Furthermore, students will participate more frequently and retain more knowledge because they understand the material in a more complex way (Emig, 1997). Teele (1996) parallels this idea saying: "intrinsic motivation, positive self-image, and a sense of responsibility develop when student become stakeholders in the educational process and accept responsibility for their own actions" (p. 72). When students understand and apply their personal intelligences, they become more connected to their learning and invested in their education. Multiple Intelligence-based instruction helps educators engage students through their natural curiosity, monopolize on teachable moments, and increase student participation through their own excitement. Goodnough (2001) states: "if students become engaged in the learning of science and develop positive attitudes toward science, there is a greater probability that they will develop high levels of scientific literacy". Educators on a global level should be exposed to literature documenting the incredible effects of MI and inspired to utilize this innovative instruction in their classrooms. Furthermore, teachers should be educated in ways to infuse their curriculum with a multiple intelligence framework to help create more authentic, engaging learning experiences for students.

\section{REFRENCES}

[1] Aschbacher, P., \& Pine, J. (2006). Students' learning of inquiry in the 'inquiry' curricula. Phi Delta Kappan, 88(2), 308-313.

[2] Baez, A. (1971). "Aims, Contents and Methodology of Science Teaching", in Science and Education in Developing States, edited by Gillon, H., Draeger Publishers, New York.

[3] Barrington, B. (2004). Teaching to student diversity in higher education: how multiple intelligences theory can help. Teaching in Higher Education, 9(4), 422.

[4] Bas, G. (2008). Integrating multiple intelligences in ESL/EFL classrooms. The Internet TESL Journal, 14(5).

[5] Bellflower, J. B. (2008). A case study on the perceived benefits of Multiple Intelligence instruction: Examining its impact on student learning. Unpublished doctoral dissertation, Fielding Graduate University, USA

[6] Campbell, L., \& Campbell, B. (1999). Multiple intelligences and student achievement : Success stories from six schools. Alexandria, VA.: Association for Supervision and Curriculum Development.

[7] Christion, M. A., \& Kennedy, D. (2004). Multiple intelligences. TESOL Journal, 6(1), 10-14.

[8] Christison, M. A. (1996). Teaching and learning language through multiple intelligences. TESOL Journal, 10-14.

[9] Cooper .F.(2008) An examination of the impact of Multiple Intelligences and metacognition on the achievement of mathematics student. Capella University.

[10] Douglas O., Burton K., smith and Durham.(2008). The Effects of Multiple Intelligence Teaching Strategy on the Academic Achievement of English Grade Math Student, Journal of Instructional Psychology,vol.35,no.2,pp:182-187 Education, 44, 288-293.

[11] Emig, V. B. (1997). A Multiple Intelligences inventory. Educational Leadership, 55 (1), 47-50.

[12] Gardner, H. (1993). Frames of mind: The theory of multiple 
intelligences. (Second Ed.). London: Fontana Press.

[13] Gardner, H. (1999). The disciplined mind: What all students should understand. New York: Simon \& Schuster.

[14] Gardner, H. (2004). Audiences for the theory of multiple intelligences. Teachers College Record, 106, 212-220.

[15] Goodnough, K. (2001). Multiple intelligences theory: A framework for personalizing science curricula. School Science and Mathematics, 101(4), 180-193.

[16] Harriman.,V.(2010).The effect of multiple intelligences teaching strategies to achievement in reading and mathematics scores. Dissertation.Submitted to the Faculty of Trevecca Nazarene University School of Education in Partial Fulfillment of the Requirements for the Degree of Doctor of Education in Leadership and Professional Practice.

[17] Johnson, M.(2007).The Effect of Multiple Intelligences on Elementary Student Performance. Submitted in Partial Fulfillment of the Requirements for the Degree PHD of Science in Education .School of Education Dominican University of California.

[18] Mussen, K.S.(2007).Comparison of the Effect of Multiple Intelligence Pedagogy and Traditional Pedagogy on Grade 5 Students' Achievement and Attitudes Towards Science, Doctoral Study Submitted in Partial Fulfillment Of the Requirements for the Degree of Doctor of Education, Walden University. Retrieved, from the ProQuest database

[19] Koksal, M. \& Yel, M. (2007). The effect of multiple intelligences theory-based instruction on attitudes towards the course, academic success, and permanence of teaching on the topic of "Respiratory Systems". Educational Sciences:
Theory \& Practice. 7, 231-239.

[20] Hurd, P.D.H. (1970). Scientific enlightement for an age of science. The Science Teacher, January, 13-15,

[21] Klopfer, L.E. (1971). Evaluation of learnings in science, In B.S. Bloom, J.T. Hastings, and G.F.Madaus. (Eds.), Handbook on Formative Summative Evaluation of Student Learning. New York, McGraw-Hill, 559-642.

[22] Kornhaber, M.L., Fierros, E., \& Veenema, S. (2004). Multiple Intelligences: Best ideas from theory and practice. Needham Heights, MA: Allyn \& Bacon.

[23] Ozdemir, P., Guneysu, S., \& Tekkaya, C. (2006). Enhancing learning through multiple intelligences. Journal of Biological Education, 40(2), 74-78.

[24] Ozdener, N., \& Ozcoban, T. (2004). A project based learning model's effectiveness on computer courses and multiple intelligence theory. Educational Sciences: Theory and Practice. 4, 176-180.

[25] Rubba, P.A. and Andersen, H.O., Development of an instrument to assess secondary school students' understanding of the nature of scientific knowledge. Science Education, 62(4): 449-458, 1978.

[26] Shore, J. (2004). Teacher education and multiple intelligences: a case study of multiple intelligences and teacher efficacy in two teacher preparation courses. Teachers College Record, 106(1), 112-139.

[27] Teele, A. (1996). Redesigning the educational system to enable all students to succeed. NASSP Bulletin, 80(583), 65-75. 